\title{
A case achieved at 28 weeks of gestation by cervical cerclage with retained placenta after expulsion of nonviable fetus underwent selective termination in multifetal pregnancy
}

\author{
Pınar Özcan (iD), Mehmet Serdar Kütük (iD), Taha Takmaz (DD , Havva Sevde İşlek (iD \\ Department of Gynecology \& Obstetrics, Faculty of Medicine, Bezmialem Vakuf University, Istanbul, Turkey
}

\begin{abstract}
Objective: We aimed to present a special case underwent the selective termination because of multiple structural anomaly and trisomy 13 in dichorionic and diamniotic pregnancy after stimulated intrauterine insemination. It achieved at 28 weeks of gestation by cervical cerclage with retained placenta after expulsion of nonviable fetus at 21 weeks of gestation which underwent selective termination at 20 weeks of gestation.

Case: Twenty-two-year-old patient (G1P0) underwent intrauterine insemination (IUI) for unexplained infertility. A dichorionic diamniotic twin pregnancy has been confirmed by the ultrasonographic examination at 12 weeks of gestation. The selective termination for twin A was performed at 20 weeks of gestation because of trisomy 13 and at 21 weeks of gestation dead twin A with ventriculomegaly, vermian agenesis, micrognathia, microphthalmia, hypertelorism, polydactyly on both hands, atrioventricular channel defect in the heart, hyperechogenic and polycystic imaging on both kidneys was delivered normally. On the absence of infection parameters, McDonaldShirodkar cerclage were carried out after the delivery of the dead twin A under antibiotherapy and tocolysis.

Conclusion: Vaginal delivery was performed and $1150 \mathrm{~g}$ male baby with 8/9 Apgar score was born at 28 weeks of gestation. Cervical cerclage may take into consideration an alternative to prolong the pregnancy, although the retention of nonviable fetal placenta following expulsion of nonviable fetus after the selective reduction may increase maternal and fetal risk.
\end{abstract}

Keywords: Dichorionic diamniotic twin pregnancy, fetal reduction, trisomy 13, cervical cerclage, IUI, structural anomaly.

\section{Özet: Çoğul gebelikte selektif terminasyon uygulanan nonviyabl fetüsün tahliyesinden sonra plasenta retansiyonlu servikal serklaj ile 28. gebelik haftasına ulaşan olgu}

Amaç: Çalışmamızda, stimüle edilmiş intrauterin inseminasyon sonrasında dikoryonik ve diamniyotik gebelikte çoklu yapısal anomali ve trizomi 13 nedeniyle selektif terminasyon uygulanan özel bir olguyu sunmayı amaçladık. Olgu, 20. gebelik haftasında selektif terminasyon uygulanan nonviyabl fetüsün 21. gebelik haftasında tahliyesi sonrasinda plasenta retansiyonlu servikal serklaj ile 28 . gebelik haftasına ulaştı.

Olgu: Yirmi iki yaşındaki hastaya (G1P0), açıklanamayan infertilite nedeniyle intrauterin inseminasyon (IUI) uyguland.. Gebeliğin 12. haftasında, ultrason muayenesiyle dikoryonik diamniyotik ikiz gebelik doğrulandı. İkiz A için 20. gebelik haftasında selektif terminasyon uyguland 1 ve 21 . gebelik haftasında ventrikülomegali, vermis agenezisi, mikrognati, mikroftalmi, hipertelorizm, her iki elde polidaktili, kalpte atriyoventriküler kanal defekti saptanan ve her iki böbrekte hiperekojenik ve polikistik görüntülemeye sahip ölü ikiz A, normal doğumla alındı. Enfeksiyon parametrelerinin olmaması üzerine, antibiyoterapi ve tokoliz altında ölü ikiz A'nın alınmasından sonra McDonald-Shirodkar serklajı uygulandi.

Sonuç: Vajinal doğum gerçekleştirildi ve 28. gebelik haftasında $1150 \mathrm{~g}$ ağırlığında, 8/9 Apgar skoruna sahip erkek bebek doğdu. Selektif redüksiyon sonrası nonviyabl fetüsün tahliyesini izleyen nonviyabl fetal plasenta retansiyonu maternal ve fetal riski artırsa da, gebeliği sürdürmek için servikal serklaj alternatif bir uygulama olarak düşünülebilir.

Anahtar sözcükler: Dikoryonik diamniyotik ikiz gebelik, fetal redüksiyon, trizomi 13, servikal serklaj, IUI, yapısal anomali.

\footnotetext{
Correspondence: Pınar Özcan, MD. Department of Gynecology \& Obstetrics, Faculty of Medicine, Bezmialem Vakıf University, Istanbul, Turkey. e-mail: drpinarozcan@hotmail.com / Received: June 3, 2019 2019; Accepted: September 3, 2019

Please cite this article as: Özcan P, Kütük MS, Takmaz T, İşlek HS. A case achieved at 28 weeks of gestation by cervical cerclage with retained placenta after expulsion of nonviable fetus underwent selective termination in multifetal pregnancy. Perinatal Journal 2019;27(2):119-124. doi:10.2399/prn.19.0272005
} 


\section{Introduction}

Multi-fetal pregnancy is a well-known, adverse outcome of stimulated IUI treatment. Multi-fetal pregnancies compared to singletons are associated with a higher risk of maternal and obstetrical complications such as miscarriage, preterm birth, low-birth weight, preeclampsia, gestational diabetes and perinatal mortality. ${ }^{[1]}$ The multiple pregnancy rate can be reduced with single embryo transfer in IVF treatment; however, in OS-IUI treatments, control of the multiple pregnancy rate is very limited.

The impact of assisted reproduction techniques (ART) on the risk of major congenital malformations (MCM) remains controversial. According to the result of studies focused on the risk of MCM associated with ART and IUI treatment, the use of ART and IUI was related to an increased risk of major birth defects (adjusted OR, 3.11; 95\% CI, 1.33-7.27 for the risk of major urogenital malformations in ART; adjusted OR, 2.02; 95\% CI, 1.10-3.71 for risk of major musculoskeletal malformations in IUI; adjusted OR, 1.66; 95\% CI, 1.00-2.79 for an increased risk of any MCM in ART, and adjusted OR, 7.18; 95\% CI, 1.59-32.53 for urogenital malformations in ART). ${ }^{[2,3]}$ Even as an adjustment, a contribution of the underlying subfertility problems cannot be completely ruled out given the differences in the severity of subfertility. There are a few studies which evaluated the risk of MCM associated with the use of stimulated IUI. Furthermore, these studies had some limitations including suboptimal sample size, lack of appropriate comparison groups and lack of the establishment of the risk of different types of congenital malformations. The incidence of fetal abnormalities has been reported to be higher in multiple pregnancies than in singletons. ${ }^{[4-6]}$

Women with multifetal pregnancies in which one fetus is abnormal and the other is normal have three options: expectant management (do nothing), terminate the pregnancy (both normal and abnormal fetuses), or selective termination (ST) of the abnormal fetus or fetuses. A specific fetus is terminated because of a structural anomaly or a chromosomal abnormality by using ST. ${ }^{[7]}$ There are several approaches which have been described for embryo reduction. ${ }^{[8,9]}$ The most commonly applied method is ultrasound-guided transabdominal injection of potassium chloride into the fetal heart. ${ }^{[10,1]}$ The technique of ST because of a structural anomaly or a chromosomal abnormality is not different from those in singleton pregnancies. But there are several additional considerations resulting from a multiple pregnancy including the procedurerelated risk of pregnancy loss, the possibility of maternal coagulopathy secondary to the prolonged retention of a nonviable fetus and the appropriate technique. The complete pregnancy loss rate of ST is at $2.5-7 \%$ and it is proportional to the starting and ending number of fetuses. ${ }^{[12-14]}$

We aimed to present a special case underwent ST because of multiple structural anomaly and trisomy 13 in dichorionic and diamniotic pregnancy after stimulated IUI. It achieved at 28 weeks of gestation by cervical cerclage with retained placenta after expulsion of nonviable fetus at 21 weeks of gestation which underwent ST at 20 weeks of gestation.

\section{Case Report}

Twenty-two-year-old patient with gravida 1, parity 0 which is not able to conceive despite a year of unprotected sexual intercourse has applied to IVF unit of Faculty of Medicine of Bezmialem University. During investigation of infertility, her hormone profile was normal, a hysterosalpingography revealed that uterine cavity was normal and the fallopian tubes were bilaterally patent. Her partner's spermiogram was consistent with normal values. The patient underwent ovulation induction and intrauterine insemination for unexplained infertility. She has got pregnant with her second ovulation induction and IUI. A dichorionic diamniotic twin pregnancy has been confirmed by the ultrasonographic examination at 12 weeks of gestation and twins had a normal nuchal translucency measurement of $1.4 \mathrm{~mm}$ and $1.6 \mathrm{~mm}$ at 12 weeks of gestation. She was referred to our perinatology clinic for the routine second trimester detailed obstetric ultrasonography at 20 weeks of gestation. An anomaly scan was performed at 20 weeks of gestation. In the ultrasonographic examination, Twin A had multiple fetal abnormalities, which strongly suggest trisomy 13 , including ventriculomegaly, vermian agenesis, micrognathia, microphthalmia, hypertelorism, polydactyly on both hands, atrioventricular channel defect in the heart, hyperechogenic and polycystic imaging on both kidneys (Fig. 1). Twin B showed normal fetal anatomy without 

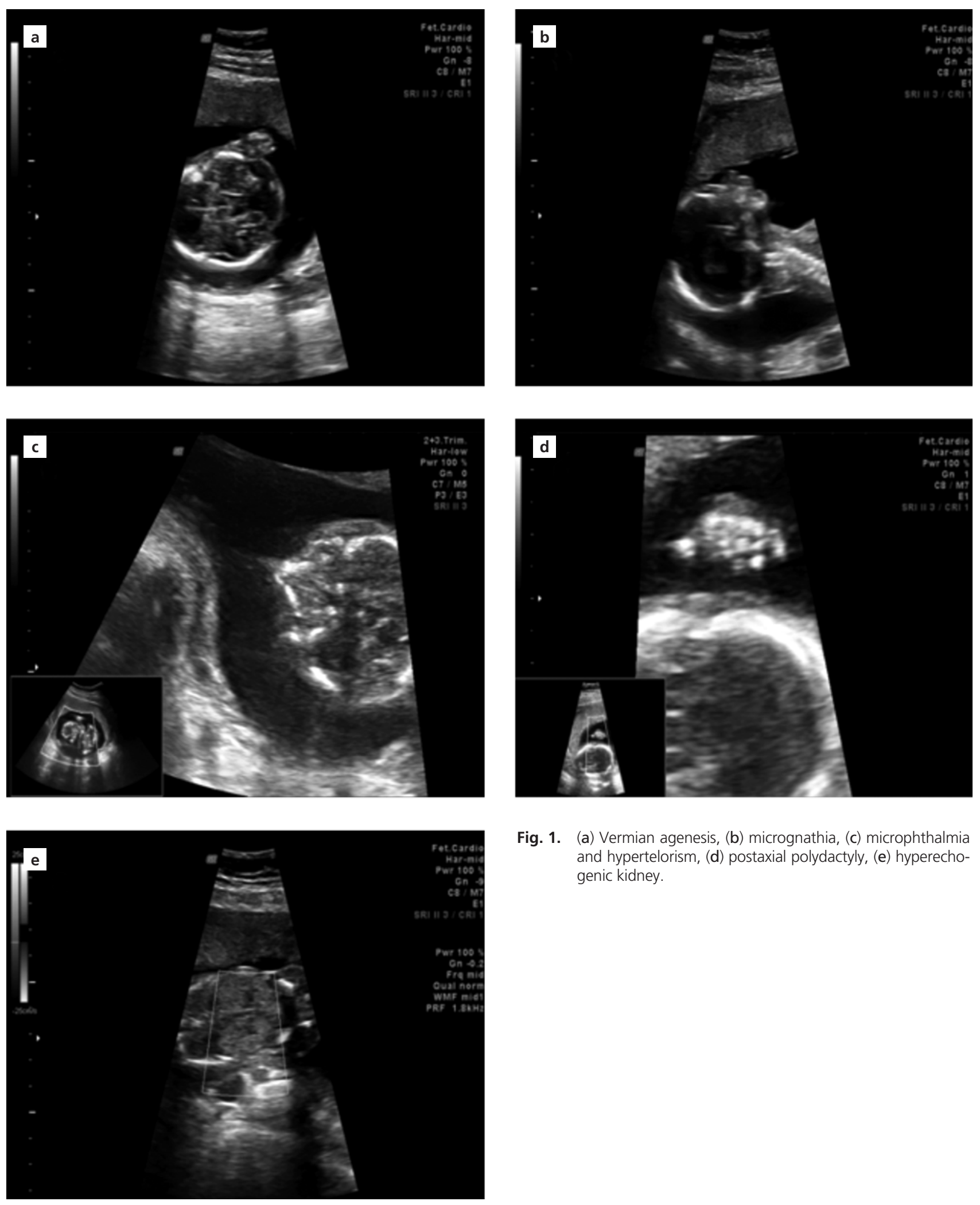

Fig. 1. (a) Vermian agenesis, (b) micrognathia, (c) microphthalmia and hypertelorism, (d) postaxial polydactyly, (e) hyperechogenic kidney. 
detected major and/or minor abnormality. The family was informed about the risk of pregnancy and genetic consultancy was provided about genetic abnormality and MCM. Counseling contained detailed discussion of the risk of mid-term ST procedure which includes $3-7.5 \%$ risk of total pregnancy loss. ${ }^{[15]}$ The family was also informed that Trisomy 13 is universally lethal condition and continuation of pregnancy as twin might be an alternative approach although it has its attendant risks specific for multiple pregnancies and the potential need for prolonged intensive care for live-born with multiple anomalies. The parents opted for selective reduction of twin A due to their concern for prolonged suffering for the affected fetus A. ST for twin A with the presumptive diagnosis of trisomy 13 was performed by transabdominal guided intrathoracic injection of potassium chloride at 20 weeks. Amniocentesis performed during the termination procedure confirmed trisomy 13.

After ST, the patient readmitted to the hospital with vaginal bleeding at 21 weeks of gestation. She had powerful uterine contraction and the ultrasonographic examination revealed that cervical length was $20 \mathrm{~mm}$ (Fig. 2). Antibiotherapy (ampiciline+sulbactam IV 2 g/4id per day for $48 \mathrm{~h}$ followed by PO $375 \mathrm{mg} / 2 \mathrm{id}$ for 5 days plus azithromycin PO $500 \mathrm{mg}$ per day for 7 days) and tocolysis (indomethacin rectal $100 \mathrm{mg}$ once, followed by PO $25 \mathrm{mg} / 4 \mathrm{id}$ for 2 days) were started. Despite antibiotherapy and tocolysis, after fourth day of therapy, amniotic leakage occurred and the dead twin A was delivered normally with full dilated cervix but the placenta of dead twin A was not delivered. On the absence of infection parameters, McDonaldShirodkar cerclage were carried out after the delivery of the dead twin A under antibiotherapy and tocolysis. The patient was daily followed up with blood and clinic infection parameters. The patient was discharged and weekly followed up at the outpatient clinic. 15 days after cerclage, the patient readmitted with abdominal pain and vaginal bleeding. She had powerful uterine contraction and cervical length was $23 \mathrm{~mm}$ at 25 weeks of gestation. Antibiotherapy and tocolysis were started again as described above. Antenatal corticosteroids (betamethasone IM $12 \mathrm{mg} / \mathrm{d}$ for 48h) were administered to enhance fetal lung maturity. Magnesium sulfate for neuroprotection with a loading dose of $4 \mathrm{~g} I V$

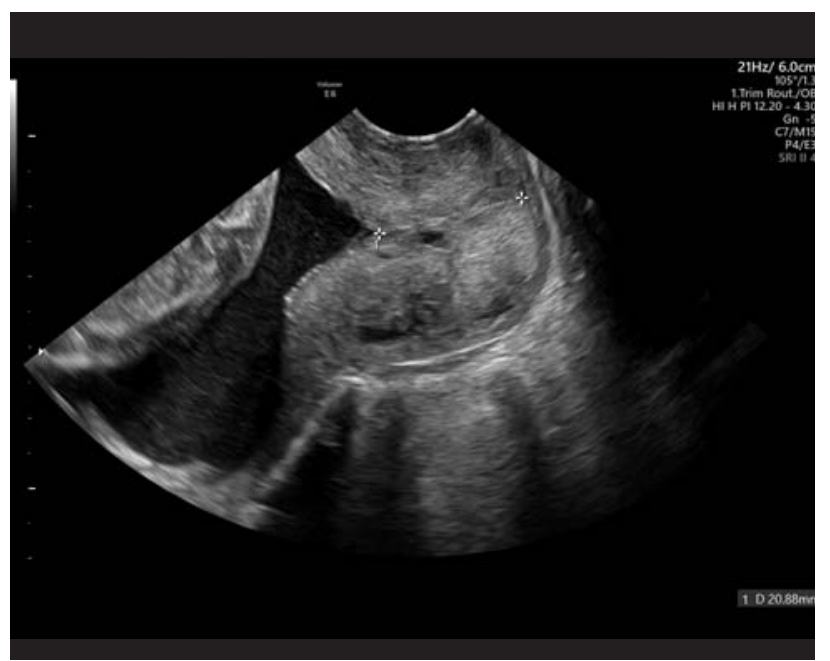

Fig. 2. $20 \mathrm{~mm}$ cervical length

in $20 \mathrm{~min}$ followed by a maintenance dose of $2 \mathrm{~g} / \mathrm{h}$ for $24 \mathrm{~h}$ was also administered. There was no response of uterine contraction to antibiotherapy and tocolysis and the presence of infection, vaginal cephalic delivery was performed and $1150 \mathrm{~g}$ male baby with 8/9 Apgar score was born at 28 weeks of gestation. During admission to NICU, the baby was not underwent intubation and it was treated with only CPAP for one week and it was stayed in neonatal unit for two months and it was discharged as $3000 \mathrm{~g}$ two months later. There was no complication related to prematurity in neonatal unit.

\section{Discussion}

We reported a special case which achieved at 28 weeks of gestation by cervical cerclage with retained placenta after expulsion of nonviable fetus with a structural anomaly and trisomy 13 underwent ST in dichorionicdiamniotic pregnancy after stimulated IUI.

Selective termination of a specific fetus in multiple pregnancy because of a structural anomaly or a chromosomal abnormality is a widely accepted procedure. However, ST of a fetus in multiple pregnancy is not similar to a singleton pregnancy, this procedure has additional factors that need to be considered in the context of a multiple pregnancy. The most unintended complication related to ST is the loss of total pregnancy before 24 weeks of gestation. The rate of unintend- 
ed pregnancy loss is generally associated with the gestational age at ST, the number of fetuses and having more than one fetus selectively terminated. The patients who had severe anomalies visible by ultrasound and invasive diagnostic procedures before $\mathrm{ST}$ is most likely have higher risk of pregnancy loss. The other important risk related to ST is the possibility of pre-term birth of a normal fetus and long-term sequelae resulted from prematurity. Preterm labor is one of the factors contributing perinatal morbidity/mortality most. The other important risk related to ST is the possibility of maternal risks arising from retention of nonviable fetal tissue following the selective reduction. After the expulsion of fetus, the retention of placenta is associated with chorioamnionitis, hemorrhage and preterm delivery. The optimal timing for performing ST has been reported in the literature to be as early as particularly before $18-20$ weeks of gestation. ${ }^{[16-18]}$ Likewise, there are several technical problems related to ST of a specific fetus in multiple pregnancy when compare to fetal reduction for elective indications in multiple pregnancy. Basically, fetal reduction for elective indications could be accompanied with fewer complications when compare to ST of a specific fetus in multiple pregnancy. ${ }^{[19]}$ Because, during fetal reduction for elective indications, the technically most easily accessible fetus can be selected to reduce as well as the fetus furthest away from the internal cervical os can be reduced to minimize the risk of premature rupture of membranes followed by premature delivery. ${ }^{[20]}$ On the other hand, selective fetal reduction is associated with excellent perinatal outcomes in dichorionic twins while selective reduction in monochorionic twins has an increased procedure-related complications and preterm delivery rate. A large single-centre series of selective fetal reduction in monochorionic and dichorionic twins for structural, chromosomal and genetic abnormalities demonstrated that ST in both monochorionic and dichorionic pregnancies is safe and effective with relatively low loss and prematurity rates. ${ }^{[21]}$ Cervical cerclage has been used widely in the management of pregnancies considered at high risk of preterm birth. Cerclage in twin pregnancies with dilated cervix $\geq 1 \mathrm{~cm}$ before 24 weeks of gestation significantly increase latency period from diagnosis to delivery (6.7 weeks). Because of longer latency period from diagnosis to delivery, it decreases incidence of spontaneous preterm birth at any given gestational age and improves perinatal outcome when compared to expectant management. ${ }^{[2]}$

The first challenge related to our case is that we had to undergo reduction of the twin closest to the cervical os for ST because the structurally or chromosomally abnormal fetus was the closest to the internal cervical os. It may be increase the risk of premature rupture of membranes after reduction. The second challenge is that the risk results from the prolonged retention of placenta of nonviable fetus after expulsion of the structurally or chromosomally abnormal fetus. We would not like to remove the placenta of abnormal fetus after expulsion of abnormal fetus because its placenta located between uterine wall and the non-affected co-twin. If we tried to remove this placenta before cervical cerclage, it would result in premature rupture of membranes of the non-affected co-twin and thus total pregnancy loss. Therefore, we performed cervical cerclage after expulsion of abnormal fetus to prolong the pregnancy and to achieve viability of the nonaffected co-twin. On the other hand, it may be considered as good prognostic factor for dichorionic twins.

\section{Conclusion}

Selective termination is a safe procedure with a low rate of pregnancy loss when performed by experienced operators. However, many of the risks related to multifetal pregnancies including preterm labor and delivery may reduce with ST so that ST would be a benefit to the remaining fetus(es) by terminating a fetus with a lethal anomaly. But unintended pregnancy loss before 24 weeks of gestation is the most important complication of ST. Cervical cerclage may take into consideration an alternative to prolong the pregnancy in those cases, although the retention of nonviable fetal placenta following expulsion of nonviable fetus after ST may increase maternal and fetal risk. Prophylactic antibiotherapy and close follow-up after cervical cerclage seems to be a reasonable choice to prevent the loss of non-affected co-twin and achieve viability of nonaffected co-twin.

Conflicts of Interest: No conflicts declared. 


\section{References}

1. Berkovitz A, Biron-Shental T, Pasternak Y, Sharony R, Hershko-Klement A, Wiser A. Predictors of twin pregnancy after ovarian stimulation and intrauterine insemination in women with unexplained infertility. Hum Fertil (Camb) 2017; 20:200-3.

2. Chaabane S, Sheehy O, Monnier P, Bissonnette F, Trasler JM, Fraser W, et al. Ovarian stimulators, intrauterine insemination, and assisted reproductive technologies use and the risk of major congenital malformations - The AtRISK Study. Birth Defects Res B Dev Reprod Toxicol 2016;107: 136-47.

3. Sagot P, Bechoua S, Ferdynus C, Facy A, Flamm X, Gouyon JB, et al. Similarly increased congenital anomaly rates after intrauterine insemination and IVF technologies: a retrospective cohort study. Hum Reprod 2012;27:902-9.

4. Bahtiyar MO, Dulay AT, Weeks BP, Friedman AH, Copel JA. Prevalence of congenital heart defects in monochorionic/diamniotic twin gestations: a systematic literature review. J Ultrasound Med 2007;26:1491-8.

5. Luke B, Keith LG. Monozygotic twinning as a congenital defect and congenital defects in monozygotic twins. Fetal Diagn Ther 1990;5:61-9.

6. Hardin J, Carmichael SL, Selvin S, Lammer EJ, Shaw GM. Increased prevalence of cardiovascular defects among 56,709 California twin pairs. Am J Med Genet A 2009;149A:877-86.

7. Berkowitz RL, Lynch L. Selective reduction: an unfortunate misnomer. Obstet Gynecol 1990;75:873-4.

8. Coffler MS, Kol S, Drugan A, Itskovitz-Eldor J. Early transvaginal embryo aspiration: a safer method for selective reduction in high order multiple gestations. Hum Reprod 1999;14:1875-8.

9. Mansour RT, Aboulghar MA, Serour GI, Sattar MA, Kamal A, Amin YM. Multifetal pregnancy reduction: modification of the technique and analysis of the outcome. Fertil Steril 1999;71:380-4.

10. Lipitz S, Shulman A, Achiron R, Zalel Y, Seidman DS. A comparative study of multifetal pregnancy reduction from triplets to twins in the first versus early second trimesters after detailed fetal screening. Ultrasound Obstet Gynecol 2001;18: $35-8$.

11. van de Mheen L, Everwijn SM, Knapen MF, Oepkes D, Engels M, Manten GT, et al. The effectiveness of multifetal pregnancy reduction in trichorionic triplet gestation. Am J Obstet Gynecol 2014;211:536.e1-6.
12. Eddleman KA, Stone JL, Lynch L, Berkowitz RL. Selective termination of anomalous fetuses in multifetal pregnancies: two hundred cases at a single center. Am J Obstet Gynecol 2002;187:1168-72.

13. Berkowitz RL, Stone JL, Eddleman KA. One hundred consecutive cases of selective termination of an abnormal fetus in a multifetal gestation. Obstet Gynecol 1997;90:606-10.

14. Evans MI, Goldberg JD, Horenstein J, Wapner RJ, Ayoub MA, Stone J, et al. Selective termination for structural, chromosomal, and Mendelian anomalies: international experience. Am J Obstet Gynecol 1999;181:893-7.

15. Eddleman KA, Stone JL, Lynch L, Berkowitz RL. ST of anomalous fetuses in multifetal pregnancies: two hundred cases at a single center. Am J Obstet Gynecol 2002;187:116872.

16. Evans MI, Ciorica D, Britt DW, Fletcher JC. Update on selective reduction. Prenat Diagn 2005;25:807-13.

17. Evans MI, Goldberg JD, Dommergues M, Wapner RJ, Lynch L, Dock BS, et al. Efficacy of secondtrimester selective termination for fetal abnormalities: international collaborative experience among the world's largest centers. Am J Obstet Gynecol 1994;171:90-4.

18. Lynch L, Berkowitz RL, Stone J, Alvarez M, Lapinski R. Preterm delivery after selective termination in twin pregnancies. Obstet Gynecol 1996;87:366-9.

19. Yılanlıglu NC, Semiza A, Arisoya R, Kahraman S, Gürkanc A. The outcome of the multifetal pregnancy reduction procedures in a single centre: a report of 202 completed cases. Eur J Obstet Gynecol Reprod Biol 2018;230:22-7.

20. van de Mheen L, Everwijn SM, Knapen MF, Haak MC, Engels MA, Manten GT, et al. Pregnancy outcome after fetal reduction in women with a dichorionic twin pregnancy. Hum Reprod 2015;30:1807-12.

20. Nobili E, Paramasivam G, Kumar S. Outcome following selective fetal reduction in monochorionic and dichorionic twin pregnancies discordant for structural, chromosomal and genetic disorders. Aust N Z J Obstet Gynaecol 2013;53:1148.

22. Roman A, Rochelson B, Martinelli P, Saccone G, Harris K, Zork N, et al. Cerclage in twin pregnancy with dilated cervix between 16 to 24 weeks of gestation: retrospective cohort study. Am J Obstet Gynecol 2016;215:98.e1-98.e11. 